This item was submitted to Loughborough's Research Repository by the author.

Items in Figshare are protected by copyright, with all rights reserved, unless otherwise indicated.

\title{
Grounded: characterising the market exit of European low cost airlines
}

\section{PLEASE CITE THE PUBLISHED VERSION}

http://dx.doi.org/10.1016/j.jairtraman.2013.08.002

\section{PUBLISHER}

(C) Elsevier

\section{VERSION}

AM (Accepted Manuscript)

\section{LICENCE}

CC BY-NC-ND 4.0

\section{REPOSITORY RECORD}

Budd, Lucy C.S., Graham Francis, lan M. Humphreys, and Stephen G. Ison. 2019. "Grounded: Characterising the Market Exit of European Low Cost Airlines”. figshare. https://hdl.handle.net/2134/13166. 
This item was submitted to Loughborough's Institutional Repository (https://dspace.lboro.ac.uk/) by the author and is made available under the following Creative Commons Licence conditions.

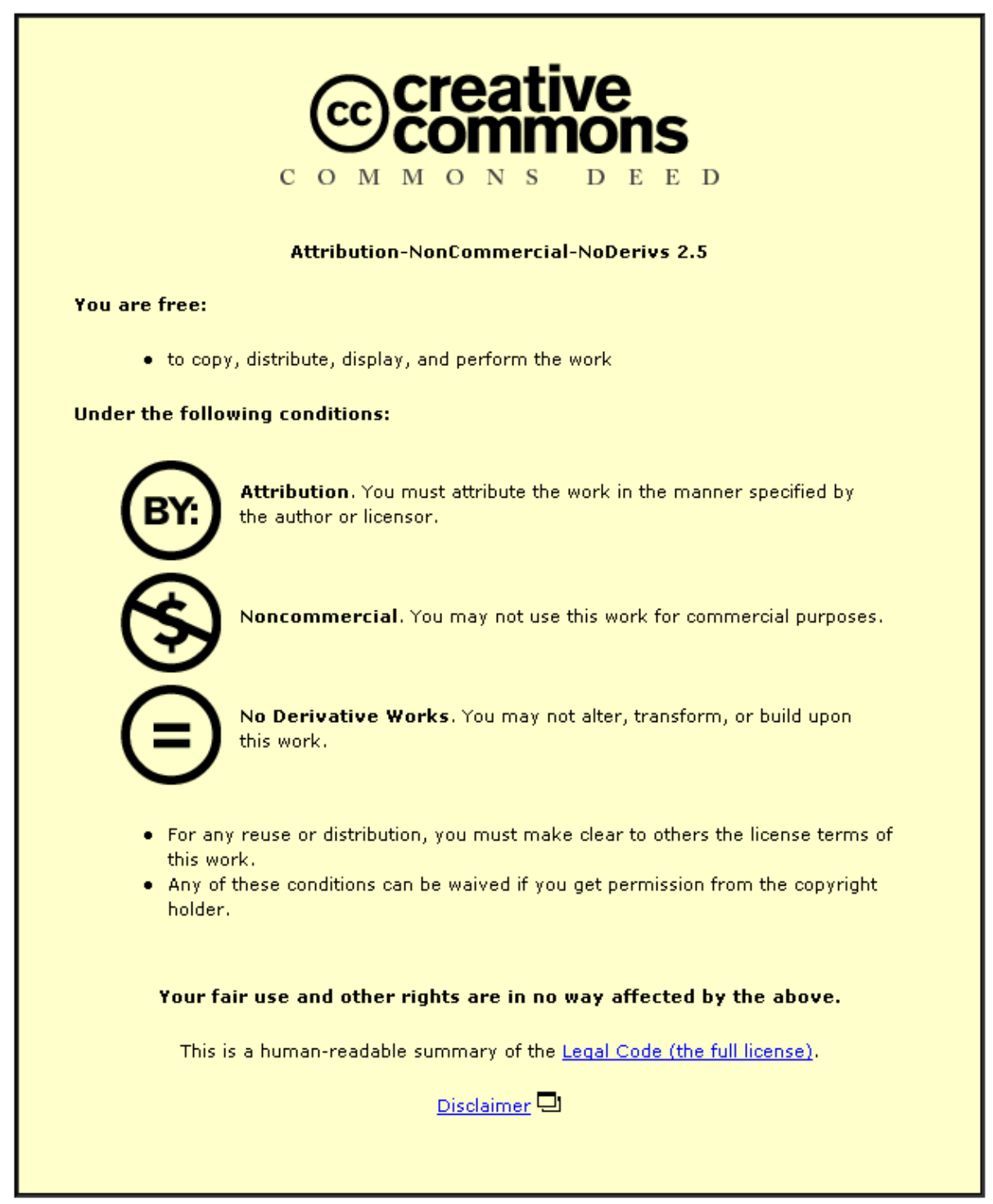

For the full text of this licence, please go to: http://creativecommons.org/licenses/by-nc-nd/2.5/ 


\title{
Grounded: Characterising the market exit of European low cost carriers
}

Lucy Budd, Graham Francis, Ian Humphreys and Stephen Ison

Transport Studies Group, School of Civil and Building Engineering, Loughborough University, UK

\begin{abstract}
The aim of this paper is to undertake a comprehensive study of LCC market entry and exit in Europe between 1992 and 2012. In the 20 year period between 1992 and 2012, 43 low cost carriers (LCCs) have taken advantage of the progressive liberalisation of the European aviation market and commenced scheduled flight operations within the continent. Of these 43 , only 10 remain operational, a failure rate of $77 \%$. This paper contributes to extant literature on LCCs by examining the market entry, business practices, operating longevity and fate of failed operators to characterise European LCC market exit. Drawing on the findings of a detailed continental-wide study, the paper identifies that an airline's start-up date, the nature and size of its operation and the size and composition of its aircraft fleet are key factors which influence LCC success and failure. The implications for both European and emerging LCC markets are discussed.
\end{abstract}

Keywords: Low cost carriers (LCCs), market exit, Europe.

\section{Introduction}

The reasons for, characteristics of and the myriad socio-economic and cultural implications resulting from policies of global airline deregulation, air transport liberalisation and the dramatic growth of low cost carriers (LCCS) worldwide have attracted considerable political, academic, and public attention. Worldwide, numerous articles, reports, and empirical analyses have been conducted into virtually every facet of LCC operation, from the corporate business philosophies, marketing, and revenue management strategies adopted by the principal protagonists, to the development of their route networks, their relationships with airports, and customer experiences of low cost flying (see Section 2). The majority of research has focused on the socio-economic benefits and 'success stories' 
associated with the emergence of a new type of airline that took advantage of the more liberalised operating environment to develop new business models and operating practices that avoided the expense associated with traditional full-service airline offerings, lowered their cost base and allowed them to pass the savings on to consumers in the form of lower fares.

Scholars from a variety of academic disciplines have examined the regional economic benefits that may result from the formation of new LCCs, the impact of new routes and destinations on competition and/or the effect of LCC product and service innovations on employees, subcontractors, consumers and competitors (see section 2). In contrast, little research has explored the characteristics of LCC failure and market exit. Considering the volatility of airlines and air traffic, particularly during periods of economic recession, this is a significant omission. It thus represents a highly topical and critical issue for policy makers, regions, airports and consumers. Certainly, the implications of routes being withdrawn, links being severed at short notice and airlines ceasing operations are potentially far reaching, especially for regions with limited alternative air service provision or sources of employment.

In response to the paucity of empirical research into LCC failure and the need to identify factors which may contribute to LCC market exit, the aim of this paper is to undertake a comprehensive study of LCC market entry and exit in Europe between 1992 and 2012. The paper begins by reviewing the salient literatures on low cost carriers before the method is described and the temporal, operational and spatial characteristics of European LCC market entry and exit are described. The paper discusses the characteristics of LCC market exit that have been identified and concludes by examining the implications of LCC market failure for airline and airport operators, competition, and consumers both within Europe and in emerging LCC markets in other world regions.

\section{The LCC phenomenon}

The emergence, expansion and evolution of low cost carriers over the last 35 years has been well documented and arguably represents one of the most significant developments in recent commercial aviation history (Calder 2002; Lawton 2002; Gross and Lück 2013). Pioneered by Texas-based Southwest Airlines and widely adopted in the immediate aftermath of the 1978 US Airline Deregulation Act, 
subsequent policies of air transport liberalisation in Europe and parts of Latin America, Africa, the Middle and Far East, Indian subcontinent and Australasia from the mid-1990s onwards (see Doganis 1994, Williams 1994, Caves 1997 and Goetz and Sutton 1997 for an overview) has meant that low cost carriers have become an increasingly global phenomenon that have dramatically reconfigured the patterns, processes, customer expectations and experiences of flight. Globally, the LCC sector has expanded rapidly to the point where LCCs now account for $22 \%$ of all passenger flights and 26\% of all airline seats worldwide (OAG, 2012). Despite significant regional variation both between and within different LCC markets, some of the most dramatic growth is currently occurring in the rapidly expanding economies and recently liberalised air transport markets in Asia and the Middle East. However, in terms of regional market penetration, LCCs have arguably had the biggest impact in Europe where they currently account for over $28 \%$ of all passenger flights (OAG, 2011).

Although there is no universally accepted definition of what constitutes a low cost carrier, Button and Ison (2008) suggest that LCCs can be distinguished from other airlines on account of the former's close adherence to many (if not all) of the following cost-minimisation strategies: To reduce maintenance and training costs, ease scheduling, and take advantage of bulk purchase discounts from manufacturers, most LCCs operate a single aircraft type (usually Boeing 737 or Airbus A320 family airframes) and a single airframe-engine combination. These aircraft are configured with an all-economy class cabin to maximise the numbers of revenue-earning seats that are available and they are flown on frequent short-haul point-to-point services, often between cheaper and less congested secondary regional airports. In order to maximise aircraft utilisation, each aircraft performs multiple services in a day and are turned around between flights in as little as 30 minutes. LCC operations are further characterised by their 'no frills' cabin service policy and limited customer service. Typically, LCCs also make extensive use of ancillary revenue generation and have transformed conventional cost items including hold baggage and in-flight catering into revenue streams. To further minimise costs, they often enter into commercial partnerships with third-party companies (such as accommodation providers and car-hire firms), subcontract aspects of their operation, 
engage in bold and often controversial marketing and use the internet for the majority of their distribution.

Much of the early literature on the emergence and growth of European low cost aviation examined the nature of the low cost model and the operating practices of its principal protagonists (see Lawton 2002; Calder 2002; Alamdari and Fagan 2005). This body of work quickly expanded to include the impact of LCCs on legacy operators and on competition (Francis et al 2007; Doganis 2010; Fageda et al 2011), examine how LCCs have changed the nature of the airline-airport relationship (Francis et al 2003, 2004; Starkie 2012; Graham, 2013) as well as the economic impact of new LCC services on patterns of business, tourism, and migration (Graham and Dennis 2010, Castillo-Manzano et al 2011). Other studies have focused on LCCs' revenue management and pricing strategies (Gillen and Morrison 2003, Alves et al 2009), their use of ICT and the internet (Hanlon 2007; Calder 2002), the spatial distribution and evolution of their route networks (Dobruszkes 2013), the charismatic management styles of LCC leadership (Calder 2002) and customer experiences of low cost flying (Mason 2000).

Crucially, and with the notable exception of Button (2012), very little has been written about LCC failure or market exit despite the volatile and highly competitive nature of the European airline sector. In order to identify the characteristics of market failure and LCC market exit in Europe, a comprehensive continent-wide study of LCC market entry and exit in Europe between 1992 and 2012 was conducted.

\section{Method}

Every low cost carrier that was registered and actively operating revenue-generating flights in Europe - defined here as members of the European Economic Area (i.e. European Union members plus Norway, Switzerland and Iceland) - between 1992 and 2012 was identified from an exhaustive online interrogation of aviation databases, airline resource sites, and academic publications. Only European airlines that flew under their own air operator's certificate and/or functioned as a distinct low cost operation were included in the study. Non-European based LCCs that serve European destinations, 'virtual' LCCs that sold tickets on behalf of other operators but who did not operate their own aircraft and 'paper' LCCs which were proposed but 
which never operated a revenue service (such as UK-based low cost operator 'Now') were not considered. Similarly airlines including Monarch (UK) and Aer Lingus (Ireland) who experimented with cost cutting in the mid-2000s but who didn't create a separate low cost subsidiary were excluded as were ad-hoc charter operators who supplied aircraft and/or crew under contract to LCCs.

One of the principal challenges inherent in this approach was the lack of a definitive and universally-accepted list of which airlines could be rightly classified as being 'low cost'. In order to resolve this issue, the extent to which each airline's business model aligned with the principal LCC operating characteristics identified by Button and Ison (2008) was used as the framework. Any carrier whose operating practices did not conform with at least eight of the defining characteristics was excluded from the study. As a result, airlines including Italian regional operator Alpi Eagles, UK regional airline FlyBe and Finnish carrier Air Finland, all of which have been identified as LCCs in some quarters, were not included (Klophaus et al, JATM 23).

The twenty year period from 1992 to 2012 was chosen as the time period of study for two reasons. Firstly, it covers the full period of European liberalisation that followed the ratification of the Third Aviation Liberalisation Package in June 1992 which facilitated the creation of a single European aviation market and secondly it includes two major phases of EU expansion in which new countries, including Poland, Hungary, Slovakia, Romania, the Czech Republic, and the Baltic States, joined the EU and extended the spatial extent of Europe's liberalised aviation market.

In all, 43 European LCCs were identified and the principal nature of their operation classified according to Francis et al's (2006) five-point low cost airline typology (Table 1). The five categories Francis et al identified are: Southwest copycats (airlines which closely adhere to the original Southwest Airlines model); FSC subsidiaries (airlines established by incumbent full-service operators to protect or capture new market share); diversified charter operators (who established a separate brand or carrier to operate low cost scheduled services); cost cutters (legacy airlines which have tackled their costs to offer a reduced service); and state subsidised carriers who complete on price. Interestingly, 42 of the 43 European LCCs identified were Southwest copycats, FSC subsidiaries or diversified charter 
operators. The only exception was UK-based Debonair which did not fit into any of the five categories (see discussion).

For each airline, the Flightglobal and airliners.net databases were interrogated to determine the date of market entry and, if applicable, the date of its final flight/market exit and fate (e.g. bankruptcy, merger, take-over or subsumed within the parent airline's operations). For the purposes of this paper, an airline was deemed to have left the market when it ceased flight operations for the final time. 
Table 1: The 43 European LCCs operational between 1992 and 2012.

\begin{tabular}{|c|c|c|}
\hline Airline & Country of origin & Type of operation \\
\hline Air Berlin & Germany & Diversified charter operator \\
\hline Air Polonia & Poland & Southwest copycat \\
\hline Air Scotland & UK & Diversified charter operator \\
\hline Air Turquoise & France & Southwest copycat \\
\hline Basiq Air & Netherlands & Diversified charter operator \\
\hline Bmibaby & UK & FSC subsidiary (bmi) \\
\hline Buzz & UK & FSC subsidiary (KLM) \\
\hline Centralwings & Poland & Southwest copycat \\
\hline Click Air & Spain & FSC subsidiary (Iberia) \\
\hline Color Air & Norway & Southwest copycat \\
\hline Dba & Germany & FSC subsidiary (British Airways) \\
\hline Debonair & UK & No category identified \\
\hline easyjet & UK & Southwest copycat \\
\hline EU Jet & Ireland & Southwest copycat \\
\hline FlyGlobespan & UK & Diversified charter operator \\
\hline Flying Finn & Finland & Southwest copycat \\
\hline FlyMe & Sweden & Southwest copycat \\
\hline FlyNordic & Sweden & Diversified charter operator \\
\hline Germania Express (gexx) & Germany & Diversified charter operator \\
\hline Germanwings & Germany & FSC subsidiary (Lufthansa) \\
\hline Get Jet & Poland & Southwest copycat \\
\hline Go & UK & FSC subsidiary (British Airways) \\
\hline Goodjet & Sweden & Southwest copycat \\
\hline HLX & Germany & Diversified charter operator \\
\hline Iceland Express/WOW & Iceland & Southwest copycat \\
\hline Jet2 & UK & Diversified charter operator \\
\hline MyAir & Italy & Southwest copy-cat \\
\hline MyTravelLite & UK & Diversified charter operator \\
\hline Norwegian & Norway & Southwest copycat \\
\hline Ryanair & Ireland & Southwest copycat \\
\hline SkyEurope & Slovakia & Southwest copycat \\
\hline Snowflake & Scandinavia & FSC subsidiary (SAS) \\
\hline Star1 & Lithuania & Diversified charter operator \\
\hline Sterling & Denmark & Diversified charter operator \\
\hline ThomsonFly.com & UK & Diversified charter operator \\
\hline Transavia & Netherlands & Diversified charter operator \\
\hline V Bird & Netherlands & Southwest copycat \\
\hline Virgin Express & Belgium & FSC subsidiary (Virgin) \\
\hline Volare Web & Italy & FSC subsidiary (Alitalia) \\
\hline Vueling & Spain & FSC subsidiary (Iberia) \\
\hline Windjet & Italy & Diversified charter operator \\
\hline Wizz Air & Poland & Southwest copycat \\
\hline Zoom UK & UK & Diversified charter operator \\
\hline
\end{tabular}




\section{Findings and discussion}

During the twenty year period under examination, 43 European-registered low cost carriers commenced operations in the continent. 17 (40\%) were Southwest copy cats, 15 were diversified charter operators (35\%) and 10 were subsidiaries of full-service carriers (23\%). The only exception was UK-based Debonair which did not fit any of the aforementioned categories. Of the 43 airlines identified, 33 have now left the market - a failure rate of $77 \%$. While this figure is considerably lower than the $94 \%$ failure rate among new entrant post-deregulation start-ups that occurred in the United States (see Gudmundsson 1998), our figures only relate to LCCs, not all new start-ups (indeed, it is appreciated that numerous other airlines, including UK-based Duo, also left the market during the period under study).

At the time of writing (July 2013), only ten carriers (Air Berlin, easyJet, Germanwings, Jet2, Norwegian, Ryanair, Transavia, Vueling, Wizz Air and WOW) are still operating and, of these, only easyJet, Ryanair, Wizz Air and WOW have stuck closely to the original Southwest-inspired low cost model. Air Berlin has joined the OneWorld airline alliance and is operating long-haul transatlantic services. Transavia of the Netherlands and Jet2 of the UK operate charter and IT services as well as low cost flights. Aircraft belonging to Spanish operator Vueling and German carrier Germanwings are used by full service operators Iberia and Lufthansa respectively and can be seen at major airports, including London/Heathrow, and Norwegian has announced plans to establish a new low cost long-haul operation using Boeing 787s. In the subsections that follow the chronology of European LCC market entry and the characteristics of market exit is examined.

\subsection{Chronology of European LCC market entry}

A chronology of European LCC market entry is presented in Table 2. From this data, it is possible to disaggregate the airlines into groups according to when they commenced operations and create a four-phase classification system of European LCC market entry. 
Table 2: Chronology of European LCC market entry.

\begin{tabular}{|c|c|c|c|}
\hline & Year & Number & Airline \\
\hline \multirow{7}{*}{ 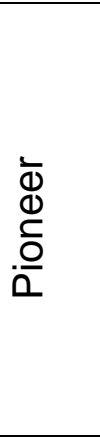 } & $\begin{array}{l}\text { Pre- } \\
1992\end{array}$ & 1 & $\begin{array}{l}\text { Ryanair (founded in } 1985 \text { as a regional operator, } \\
\text { restructured as a LCC in 1990/91*) }\end{array}$ \\
\hline & 1993 & 1 & Norwegian \\
\hline & 1994 & 0 & \\
\hline & 1995 & 1 & easyJet \\
\hline & 1996 & 2 & Debonair, Virgin Express \\
\hline & 1997 & 0 & \\
\hline & 1998 & 3 & $\begin{array}{l}\text { Air Berlin (founded in 1978, launches Mallorca shuttle and } \\
\text { seat-only low cost services in 1998**), Color Air, Go Fly }\end{array}$ \\
\hline \multirow{4}{*}{ 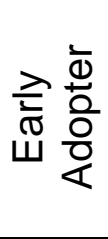 } & 1999 & 0 & \\
\hline & 2000 & 2 & Basiq Air, Buzz \\
\hline & 2001 & 0 & \\
\hline & 2002 & 6 & $\begin{array}{l}\text { Bmibaby, Germanwings, Goodjet, HLX, MyTraveLite, } \\
\text { SkyEurope }\end{array}$ \\
\hline \multirow{4}{*}{ 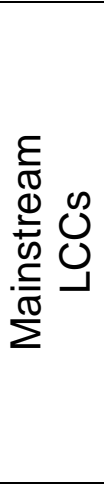 } & 2003 & 13 & $\begin{array}{l}\text { Air Polonia, Air Scotland, dba, EU Jet, FlyGlobespan, } \\
\text { FlyingFinn, Germania Express, Get Jet, Iceland Express } \\
\text { (now WOW), Jet2, Snowflake, VBird, WindJet }\end{array}$ \\
\hline & 2004 & 6 & $\begin{array}{l}\text { FlyMe, FlyNordic, MyAir, ThomsonFly.com, Vueling, Wizz } \\
\text { Air }\end{array}$ \\
\hline & 2005 & 4 & $\begin{array}{l}\text { Air Turquoise, CentralWings, Sterling, Transavia.com } \\
\text { (Transavia founded in 1965, established subsidiary low } \\
\text { cost brand Basiq Air in 2000, merged Basiq Air and } \\
\text { Transavia to form transavia.com } \text { co**}^{\star *} \text { ) }\end{array}$ \\
\hline & 2006 & 2 & Click Air, Zoom UK \\
\hline \multirow{6}{*}{ 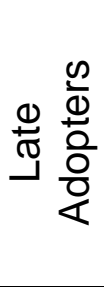 } & 2007 & 0 & \\
\hline & 2008 & 1 & VolareWeb \\
\hline & 2009 & 1 & Star1 \\
\hline & 2010 & 0 & \\
\hline & 2011 & 0 & \\
\hline & 2012 & 0 & \\
\hline
\end{tabular}

\subsubsection{Pioneers (1992-1998)}

Between 1992 and 1998, eight carriers commenced low cost operations in Europe. Some, including Ryanair (Ireland), Norwegian and Air Berlin commenced operations before 1992 but restructured their operations to become low cost operators to take advantage of the more liberalised operating environment. Others, including UKbased easyJet, were new start-ups who sought to emulate the success of Southwest Airlines by adopting many of the features of Southwest's business model (a so-called Southwest copycat). Collectively, these nine airlines pioneered low cost flying in Europe and also, crucially, benefited from first mover advantage and the relative lack of low cost competition (see Gillen and Morrison 2003). Significantly, four (50\%) of 
these pioneering LCCs - Air Berlin, easyJet, Norwegian and Ryanair - are still operational while the four that have left the market operated for an average of 8.5 years.

\subsubsection{Early Adopters (1999-2002)}

The success of the pioneering LCCs and the continued liberalisation of the European air transport market during the late 1990s resulted in a new group of LCCs commencing flight operations between 1999 and 2002. Like the pioneers, most of these early adopters - Basiq Air (Netherlands), bmibaby, Buzz and MyTraveLite (all UK), Goodjet (Sweden), HLX and Germanwings (Germany) - were based in northwest Europe (Slovakia's Sky Europe was the notable exception). 75\% of these early adopters were either subsidiaries of existing full service carriers or had been established by charter operators who had diversified into the LCC sector. Bmibaby was formed by full-service UK operator bmi british midland international in 2002 to counter the competitive threat posed by British Airways' LCC subsidiary Go-Fly commencing operations from bmi's regional base at East Midlands Airport. Buzz was established by KLM/UK to protect their market share at London/Stansted from the rapid expansion of Ryanair while the German national carrier, Lufthansa, founded its own LCC subsidiary, Germanwings. Charter airlines MyTravel (UK), Hapag Lloyd (Germany) and Transavia (Netherlands) similarly responded with their own low cost operators - MyTraveLite, HLX (Hapag Lloyd Express), and Basiq Air respectively - to counter the emerging LCC threat.

Of the eight early adopters only one - Germanwings - is still operating (a failure rate of $88 \%$ ). The seven carriers that left the market flew for an average of 5.7 years compared to the 8.5 achieved by the failed pioneer operators. Bmibaby was unusual in that it flew for 10 years (2002-2012) before being closed by its new parent company IAG (International Airlines Group) after it was put up for sale but failed to find a buyer.

\subsubsection{Mainstream LCCs (2003-2006)}

The majority of European LCCs commenced operations between 2003 and 2006. During this period, 25 airlines commenced operations in 11 different European countries. Of the 25 new start-ups, only five - Iceland Express (subsequently 
rebranded as WOW), Jet2 (UK), Vueling (Spain), Transavia.com (formed as a result of a merger between charter operator Transavia and its low cost subsidiary Basiq Air) and Wizz Air (Hungary) - are still flying, representing a failure rate of $80 \%$. Unlike the early adopters, only 52\% of LCC start-ups in this period were diversified charter operators or FSC subsidiaries. The remaining 48\% were Southwest copy cats. This suggests that many of the existing carriers who wanted to establish a low cost operation had already done so. The 20 mainstream LCCs that have now left the market operated for an average of only 4.1 years.

\subsubsection{Late Adopters (2007-2012)}

Two airlines, Lithuanian-based Star1 and Italian operator VolareWeb, entered the market relatively late in 2008 and 2009 respectively and represented an attempt by existing operators to try and break into the low cost market. These carriers only lasted an average of 2 years before ceasing operations.

\subsection{Chronology and typology of LCC market exit}

In addition to categorising LCCs according to the year they entered the market, a number of significant spatial, temporal, and operational characteristics relating to LCC failure and market exit in the European LCC sector can be identified. Initially, low cost flying was largely a phenomenon of the more industrialised and economically prosperous countries of northwest Europe before it spread south and east to the Mediterranean and Central and Eastern Europe at the turn of the millennium. As Dobruszkes (2013) has shown the expansion of LCC services to and within Central and Eastern Europe parallels EU enlargement and the accompanying expansion of the liberalised market. However, the number of subsequent LCC failures indicates that the supply of flights between certain airport pairs and within certain countries outweighed consumer demand for flights while intense competition between airlines forced financially weaker operations to leave the market.

Although it has become something of a cliché to assert that it is possible to learn more from failure than it is from success, it can be instructive to examine past performance to try and identify characteristics of market failure in order to try and avoid their repetition. In this section of the paper, the focus is specifically on the temporal, spatial, and operating characteristics of the 33 European LCCs that left the 
market between the year of the first failure, in 1999, and 2012. The operating history of the 33 failed airlines is presented in Figure 1.

Figure 1: Operating history of the 33 failed European LCCs.

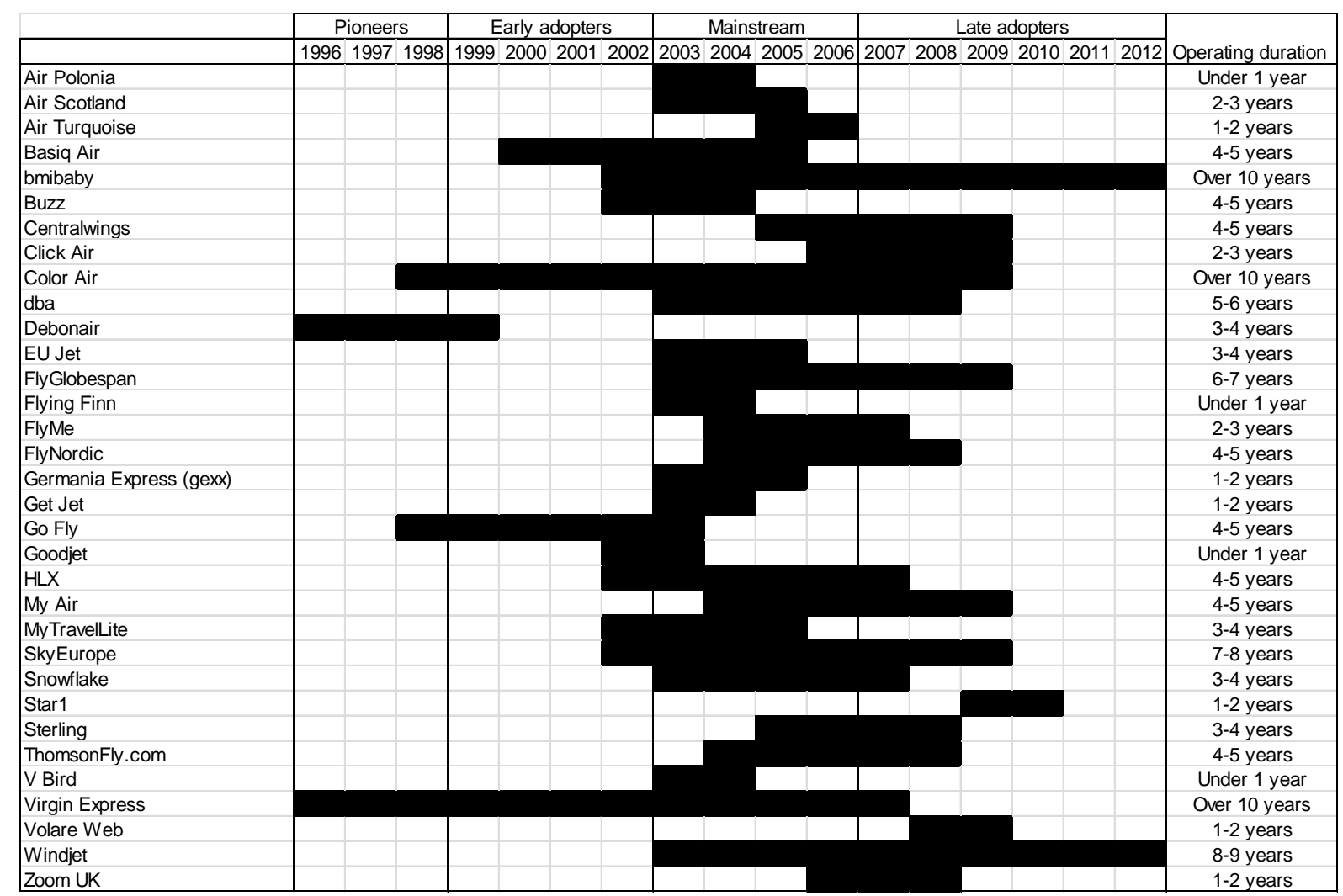

Collectively, the 33 failed LCCs had relatively short operating histories and flew for an average of 4.7 years. Five (15\%) failed within a year of commencing operations, 26 (79\%) failed within 5 years, and 30 (91\%) failed within a decade. Only three LCCs operated for over 10 years and all were subsidiaries of existing travel companies (Norwegian LCC Color Air was owned by the Color Shipping Line, Brussels-based Virgin Express by the Virgin Group, and bmibaby by bmi british midland and then IAG).

The first failure and market exit of a European LCC involved London/Luton-based UK operator Debonair in 1999. Debonair was unusual in that it didn't adhere to the traditional low cost Southwest-inspired business model. It operated a fleet of fourengined 112-seat BAe146-100 and -200 aircraft as opposed to the more 
conventional B737-800 (189 seats) or A319 (156 seats) and attempted to introduce 'Affordable Business Class' into the market and serve major (and hence more expensive) European airports. As a consequence, Debonair's cost structure was such that the airline was unable to maintain operations beyond 1999. The next two market exits involved British Airways' subsidiary Go (following a management buyout and subsequent acquisition by easyJet) and Swedish operator Goodjet in 2003. Between 2003 and 2006, 14 LCCs left the market - many due to bankruptcy. A further wave of failure, which occurred between 2007 and 2009 (Figure 2) almost certainly resulted from a period of high and volatile oil prices and the effects of the global economic recession.

Figure 2: Comparison of European LCC start-up and failure dates.

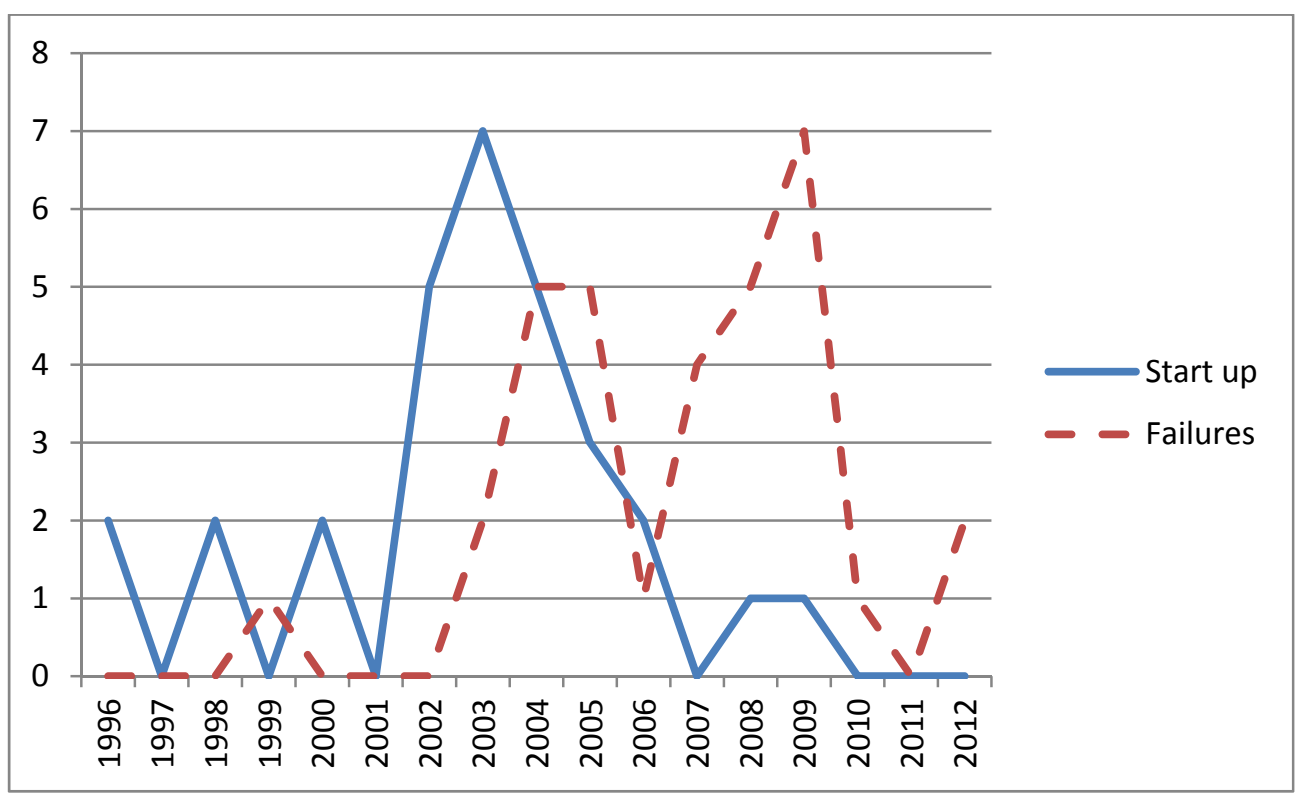

While it may be possible to map LCC failure to world events to offer an explanation for their demise, it is also necessary to examine both when the failed LCCs commenced operations and also which type of LCC model they adopted to ascertain whether particular types of operation were more or less vulnerable to failure. Significantly, the later an airline commenced operations, the shorter its average period of operation (Figure 3). 
Figure 3: Average operating duration of the failed LCCs (years).

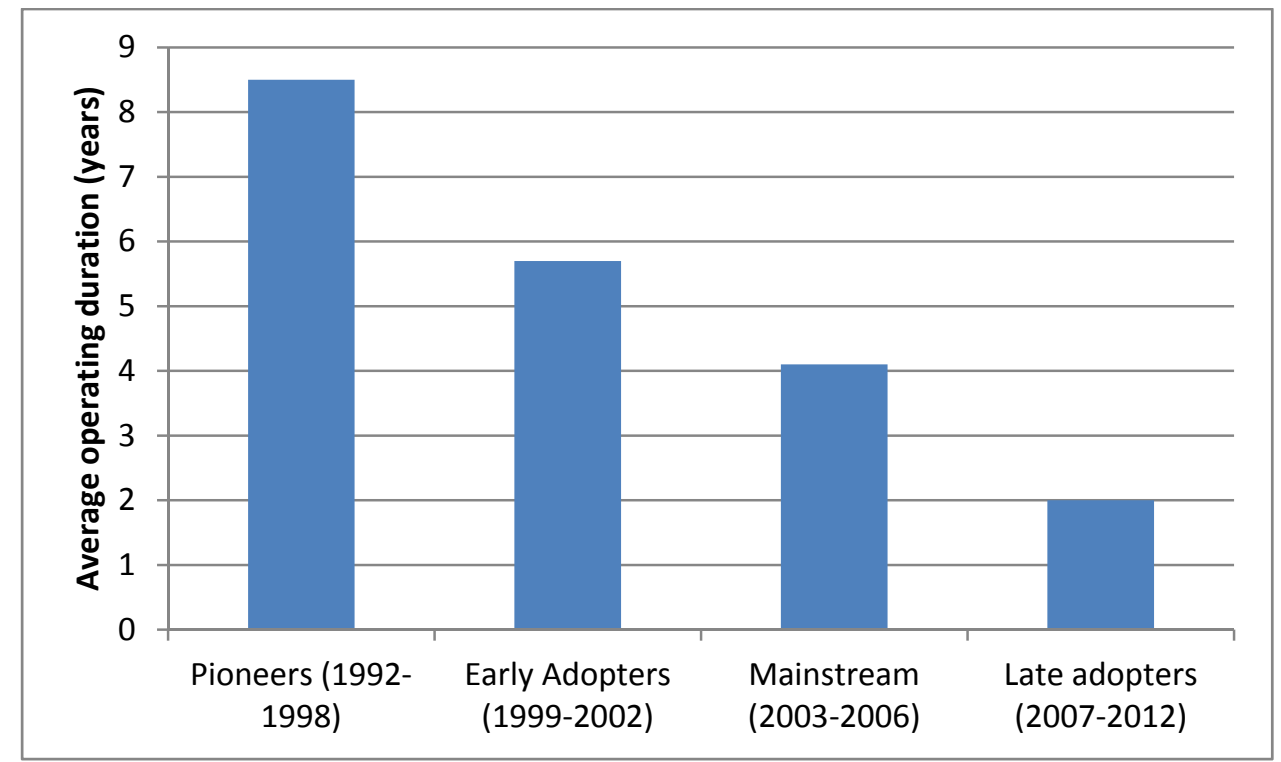

The four failures among the pioneering LCCs operated for an average of 8.5 years. This compares with 5.7 years for the 7 failed early adopters, 4.1 years for the 21 failed mainstream LCCs and 2 years for the 2 failed late adopters. The fact that later entrants into the market have struggled suggests that they tried to enter a market that was already saturated and too price competitive, with the result that the supply of low cost flights outweighed consumer demand for the services and existing LCC operators were able to use their market power and superior financial resources to see off new competitive threats. However, in addition to the year they entered the market, other factors are likely to have contributed to their failure.

Based on Francis et al's (2006) typology of LCC business models, it was found that $12(35 \%)$ of the failed LCCs were Southwest copycats, 12 (35\%) were diversified charter operators, 9 (27\%) were FSC subsidiaries and one (Debonair) didn't follow any particular model. In total, $59 \%$ of failures occurred among LCCs affiliated to or operated by existing FSCs and charter airlines. Were it not for the fact that 7 of the 9 surviving European LCCs were established by existing operators, this would appear to suggest that existing airlines find it hard to culturally adapt to the LCC model or, conversely, they considered that their LCC subsidiaries were becoming too successful (either through threatening the competitive position of the parent carrier 
by undermining its market share or diluting the main brand) and were thus reabsorbed into the main carrier or disbanded.

However, when one considers that of the remaining nine operational LCCs, two (Germanwings and Vueling) are direct FSC subsidiaries, Air Berlin, Norwegian and Ryanair are the results of regional carriers that restructured their operations to become LCCs (although Air Berlin has recently moved away from this model), Jet2 was established by UK cargo operator Channel Express and Transavia.com was formed as a result of a merger between charter carrier Transavia and its low cost subsidiary Basiq Air this theory does not appear to be true. Indeed, only easyJet and Iceland Express (now flying as WOW) were established as standalone Southwest copycats. These findings appear to suggest that more complex interactions than simply date of market entry and type of business model are at work.

\subsection{Ownership characteristics of failed LCCs}

$50 \%$ (17 of the 34 ) failed European LCCs were 'privately owned' by individuals or by corporations that previously had no involvement in commercial aviation activities. A further 11 (32\%) were owned or established by existing airlines and/or travel companies. The ownership of the remaining six could not be conclusively determined. In terms of operational success, the majority of privately owned LCCs failed less than two years after they were formed whereas airline-owned LCCs fared better. $60 \%$ of FSC subsidiaries and diversified charter operators lasted for more than four years before ceasing operations and three operated for over 10 years.

LCCs that were owned or established by an existing airline had the inherent advantage of having access to experienced managers who could devise (and then often be seconded to run) the new operation. The original Chief Executive of UKbased Go, Barbara Cassani, for example, moved from her post within British Airways to lead the new low cost venture. A further advantage for airline-owned LCCs is that they may also have the financial and/or organisational backing of the parent company (such as Channel Express' support for Jet2 and TUl's for Thomsonfly) and thus have immediate access to suitable aircraft, trained engineers, a pool of qualified flight crew and ground staff, and access to established online computer reservation 
systems. They may also conversely, however, be potentially disadvantaged by the historical legacy and operational inertia of the parent company.

Some of the FSC subsidiaries and diversified charter LCCs analysed ceased operations following strategic decisions taken by their parent companies to halt LCC services and concentrate on their core brand. Independent LCC operators, on the other hand, while they may not have enjoyed such generous financial backing or access to immediate technical and human resources may have been able to be more flexible and innovative. Indeed, it is often the originally independent and privately-owned LCCs, like easyJet, who have driven developments in ICT, internet reservations and social media and taken inspiration from other areas of corporate business strategy and successfully applied them to the commercial aviation sector.

\subsection{The relative 'size' of failed LCCS}

In addition to the date when they entered the market and their ownership structure, the relative 'size' of individual LCCs and the strategic decisions they make about aircraft are also important indicators of likely success or failure. Although the relative 'size' of airlines can be measured by a number of individual metrics, including annual revenue passenger kilometres, number of employees, number of routes operated, number of different countries served, number of passengers transported and operating revenue, use is made of the number of destinations served and the number and composition of aircraft in their fleet at the point they ceased operations as a proxy for the relative size and scope of their operations (Table 3).

Table 3: Comparative size of the failed LCCs at time of closure (-) indicates where data could not be accurately determined or verified.

\begin{tabular}{llll}
\hline Airline & $\begin{array}{l}\text { Destinations } \\
\text { served }\end{array}$ & $\begin{array}{l}\text { Fleet } \\
\text { size }\end{array}$ & Fleet composition* \\
\hline Air Polonia & 28 & 6 & $2 \times \mathrm{B} 734,2 \times \mathrm{B} 733,2 \times$ Let410 \\
Air Scotland & 15 & 3 & $2 \times \mathrm{B} 752,1 \times \mathrm{A} 320$ \\
Air Turquoise & 4 & 1 & $1 \times \mathrm{ATR} 42-500$ \\
Basiq Air & 24 & 3 & $3 \times \mathrm{B} 737$ \\
Bmibaby & 23 & 14 & $12 \times \mathrm{B} 733,2 \times \mathrm{B} 735$ \\
Buzz & 24 & 12 & $6 \times \mathrm{BAe} 146,6 \times \mathrm{B} 733$ \\
Centralwings & 56 & 12 & $1 \times \mathrm{MD} 80,3 \times \mathrm{B} 733,8 \times \mathrm{B} 734$ \\
Click Air & 41 & 26 & $26 \times \mathrm{A} 320$ \\
Color Air & 6 & 3 & $3 \times \mathrm{B} 733$
\end{tabular}




\begin{tabular}{|c|c|c|c|}
\hline Dba & 43 & 48 & $32 \times$ B733, $2 \times$ BAe146, 14 F70/100 \\
\hline Debonair & 9 & 16 & $3 \times \mathrm{B} 733,13 \times \mathrm{BAe} 146$ \\
\hline EU Jet & 21 & 6 & $6 \times \mathrm{F} 100$ \\
\hline FlyGlobespan & 26 & 9 & $2 \times \mathrm{B} 737,3 \times \mathrm{B} 738,4 \times \mathrm{B} 763$ \\
\hline Flying Finn & 5 & 2 & $2 \times \operatorname{MD} 83$ \\
\hline FlyMe & 25 & 6 & $5 \times \mathrm{B} 733,1 \times \mathrm{B} 735$ \\
\hline FlyNordic & 16 & 7 & $3 \times \mathrm{MD} 82,4 \times \mathrm{MD} 83$ \\
\hline Germania Express (gexx) & 15 & 12 & $12 \times \mathrm{F} 100$ \\
\hline GetJet & - & - & - \\
\hline Go Fly & 31 & 27 & $27 \times B 733$ \\
\hline Goodjet & 8 & 8 & $6 \times \mathrm{A} 320,1 \times \mathrm{B} 733,1 \times \mathrm{B} 752$ \\
\hline HLX & 37 & 19 & $17 \times \mathrm{B} 733,2 \times \mathrm{F} 100$ \\
\hline MyAir & 27 & 8 & $3 \times \mathrm{A} 320,4 \times \mathrm{CRJ} 900$ \\
\hline MyTravelLite & 10 & 4 & $4 \times A 320$ \\
\hline SkyEurope & 30 & 13 & $7 \times \mathrm{B} 733,2 \times \mathrm{B} 735,4 \times \mathrm{B} 737$ \\
\hline Snowflake & - & 4 & $2 \times \mathrm{MD} 82,2 \times \mathrm{B} 738$ \\
\hline Star1 & 9 & 1 & $1 \times \mathrm{B} 737$ \\
\hline Sterling & 39 & 27 & $4 \times \mathrm{B} 735,15 \times \mathrm{B} 737,7 \times \mathrm{B} 738,1 \times \mathrm{MD} 83$ \\
\hline ThomsonFly.com & - & 4 & $4 \times B 735$ \\
\hline V Bird & 15 & 4 & $4 \times \mathrm{A} 320$ \\
\hline Virgin Express & 24 & 10 & $5 \times \mathrm{B} 733,5 \times \mathrm{B} 734$ \\
\hline Volare Web & 4 & 2 & $2 \times A 320$ \\
\hline Windjet & 26 & 12 & $12 \times \mathrm{A} 230$ \\
\hline Zoom UK & 10 & 3 & $1 \times B 762,2 \times B 763$ \\
\hline
\end{tabular}

${ }^{*} \mathrm{~A} 320=$ Airbus A320, BAe146 = British Aerospace BAe146, B733 = Boeing 737-300, B734 = Boeing 737-400, B735 = Boeing 737-500, B737 $=$ Boeing 737-700, B738 $=$ Boeing 737-800, B752 $=$ Boeing 757-200, B762 = Boeing 767-200, B763 = Boeing 767-300, CRJ900 $=$ Canadair Regional Jet 900, $\mathrm{F} 100=$ Fokker 100. MD80/82/83 $=$ McDonnell Douglas MD80/82/83. Fleet data derived from planespotters.net, 2013.

Based on available data, the 33 failed operators flew to an average of 22 destinations. The scope of LCC operations ranged from Air Turquoise, which only served 4 destinations, to Centralwings which served 56 . Collectively, the failed LCCs operated an average of 10 aircraft (ranging from one in the case of Air Turquoise to 48 in the case of $d b a)$.

Of the 332 aircraft these LCCs collectively operated, $57 \%$ were B737 family and $18 \%$ were A320 family members (e.g. A319s, A320s or A321s) with smaller numbers of Fokker 70s and Fokker 100s (10\%), BAe146s (6\%) and MD80/82/83s (4\%) (see Figure 5). The remaining proportion was made up B767s, CRJ900s, B757s, Let 410s and a single ATR42-500. Over 99\% were jet aircraft and only 1\% (3 aircraft) were turboprops (two Let 410s and a single ATR-42). 
Figure 5: Type of aircraft operated by the failed LCCs.

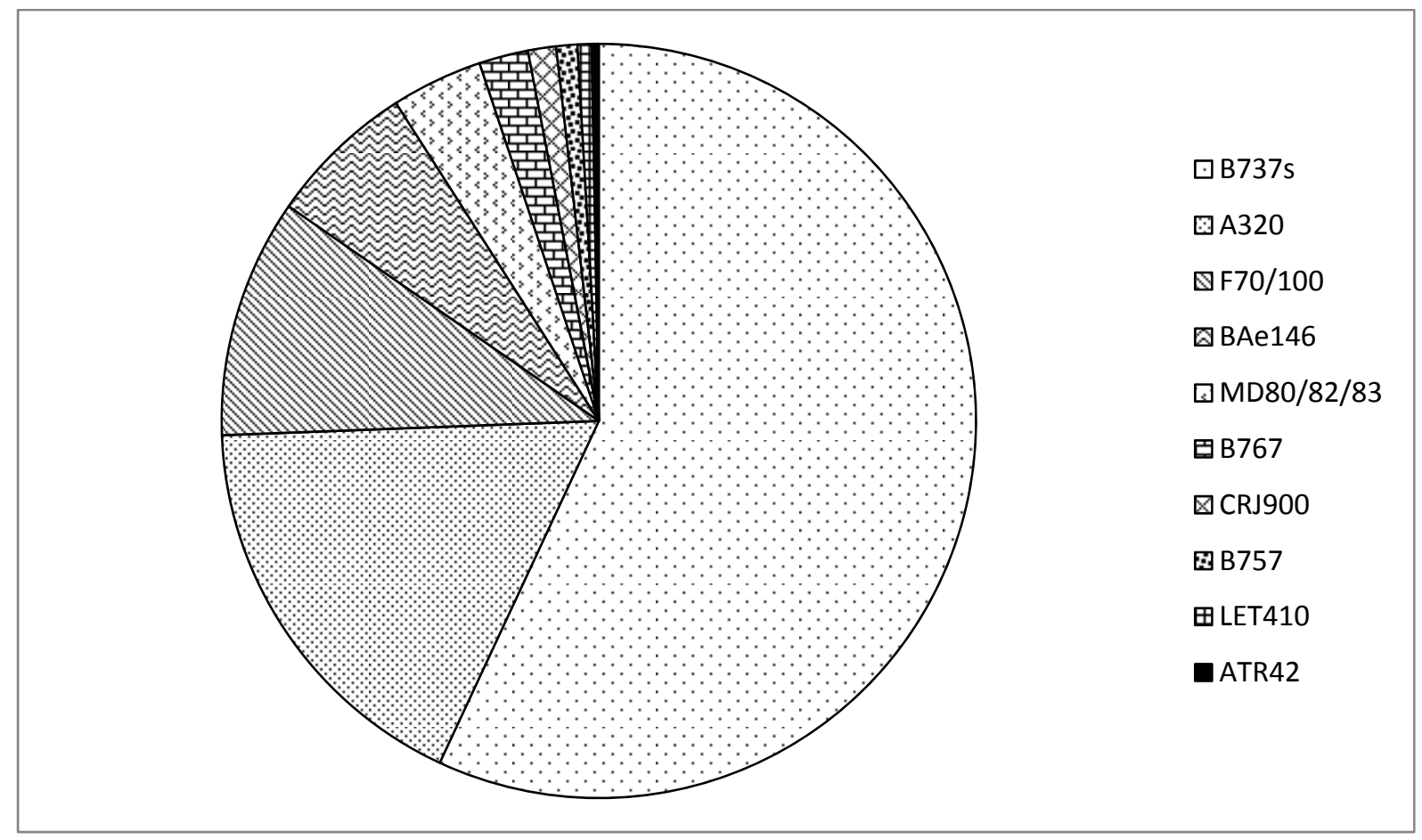

Of the 32 of the 34 failed LCCs for which fleet data is available, $60 \%$ operated one type of aircraft, 31\% flew 2 and 9\% operated 3. In this context, B737 Classics (i.e. B737-300, B737-400 and B737-500 series) were distinguished from Next Generation $B 737-700$ and B738-800 airframes. MD80/82/83 were counted as one type as were F70/100 and Boeing 767-200s and -300s on grounds of type commonality and multiaircraft type rating.

In contrast, at the time of writing, 6 of the 9 surviving LCCs operate a single type of aircraft, Jet2 operate 2 (B737-300 and B757-200), Norwegian operate 3 (B737-300 and B737-800 and A340 respectively) and Air Berlin operate 5 (A320 family, A330, B737NG family, Dash-8, and ERJ-190). Thus fleet diversity (which conventionally has been seen as a detriment to a low cost base) does not appear to be a barrier to success. What is interesting, however, is the aircraft mix of surviving LCCs. Of the 854 aircraft they collectively operate $98.8 \%$ are jets and $1.2 \%$ are props (Dash-8s). Just under half (49.5\%) are B737NGs and 43\% are A320 family aircraft. Similarly, although the number of aircraft and the 'size' of an airline's operation undoubtedly confers significant economies of scale, not all the surviving LCCs have large fleets. Although Ryanair with 303 B737-800s has the largest fleet and both easyJet and Air 
Berlin operate 193 and 122 aircraft respectively, 5 operators fly fewer than 41 aircraft and WOW has only two.

\subsection{The geography of European LCC failure}

LCC success and failure in Europe has a significant spatial dimension. The first LCCs to enter the market were predominately based in countries of northwestern Europe and initially began flying services between secondary or regional airports in the hinterland of major European cities (the only notable early exception to this was Virgin Express who were based at Zanvantem airport). As a consequence, they initially avoided direct airport-pair competition with incumbent full-service operators and were able to carve out a distinct operating niche that complemented, rather than directly competed with, existing FSC and regional airline services. Although liberalisation is a feature of all EU member states, LCCs have only emerged in a few countries. The 34 LCCs that left the market originated in 16 different countries although of these, almost a third (29\%) were registered in the UK (one of the first countries to liberalise bilateral air service agreements) while a further 3 each came from Italy, Germany and Sweden. LCC Snowflake was unusual in that it was a subsidiary of the pan-national SAS (formerly Scandinavian Airlines System). While it is possible to advance speculative theories as to why Austria, Greece, Luxembourg, Portugal, and Switzerland have not been the home of LCCs start-ups, proving direct causal relationships is fraught with difficulty and thus regrettably remains beyond the scope of this paper.

\section{Conclusion}

While it is appreciated that airline failure and volatility is of course not restricted to the low cost sector, it is important to note that studies of LCCs have often focused on their success and their impact on competition and legacy carriers. While it is very difficult to create a guaranteed recipe for LCC success, our research has shown there are a number of features that characterise failed carriers and it is to these characteristics the final section of the paper now turns.

As Alamdari and Fagan (2005) suggested, strict adherence to the original Southwest inspired low cost model appears to be an important element of success. This requires carriers to only fly one type of aircraft to keep costs low and select an 
aircraft that seats over 130 passengers and offers both good service reliability and fuel efficiency. It also requires carriers to identify routes that will generate sufficient, sustained and preferably year-round long-term demand and revenues. Indeed, it could be argued that a number of LCCs have failed as a result of the routes they operated and the aircraft they flew. UK-registered LCC EUJet, for example, flew a fleet of Fokker 100 aircraft on services to/from the relatively inaccessible Manston Airport in Kent but was unable to generate the financial returns required to remain operational. In contrast, Ryanair has developed into a highly successful low cost operator that flies 303 B737-800 aircraft and over 79 million passengers a year to/from multiple destinations at secondary airports across Europe (Ryanair 2013) while easyJet has grown from an operation employing two leased aircraft in 1995 to an airline operating 193 aircraft and carrying over 59 million passengers a year in 2012 (easyJet 2013).

If it is possible to define a recipe for success, creating a strong and memorable brand and product, being one of the first entrants into a market, basing operations somewhere in north-western Europe, adhering to the original Southwest Airlines LCC model and/or securing the backing of an existing airline, employing modern B737 or A320 family aircraft on short-haul point-to-point services, growing expeditiously as market conditions dictate, and vigorously defending their market share and avoiding direct competition with rivals appears to offer a good start. Several of the successful pioneering LCCs have also been led by a charismatic and often controversial figurehead who attracts and maintains media interest in the company.

LCCs that have failed have typically been 'smaller' in terms of resources, fleet size, and the scale and scope of their operation and thus more vulnerable to bankruptcy or take-over. Many failed operators did not strictly adhere to the original low cost model and/or branched out into new and ultimately unprofitable ventures such as Debonair's 'Affordable Business Class' product and the failed 'low cost' business class only airlines Silverjet, Eos and MaxJet. Other operators have suffered because they arguably failed to sufficiently differentiate themselves from the parent brand (e.g. MyTravelLite and Thomsonfly), entered the market relatively late and so lacked first mover advantage (e.g. Star1), or employed aircraft that were costly to maintain and 
fuel inefficient (e.g. EUJet's 100 seat Fokker 100s and Debonair's fleet of 112 seat BAe-146s).

While European air transport liberalisation undoubtedly introduced some welcome dynamism and competition into the airline market, the transition from a regulated to a more open market has not always been smooth. Although the newly liberalised operating environment enabled new carriers to commence operations, it also created a situation in which arguably too many airlines were competing for too few customers. Early adopters of the low cost airline model were largely successful in stimulating new demand for their services and growing their business but later entrants found it increasingly difficult to compete and $77 \%$ of European LCCs start-ups have now failed. Given continuing global economic uncertainty in Europe combined with a relatively mature and increasingly saturated market, it is contended that, in the short term, opportunities for new LCCs in most areas of Europe are limited. Consequently, any substantial LCC growth is likely to occur in other world regions, including the Middle East, Far East and Africa, which are reconfiguring and deregulating their air transport markets. Indeed, it would appear that there are opportunities in these regions for European LCCs to grow their business and/or establish new ventures to grow new markets as the formation of the pan-African LCC Fastjet by easyJet's Sir Stelios Haji-loannou has recently demonstrated. Given the experience of LCC market entry and exit in the US and Europe, similar cycles of dramatic growth and decline in these world markets appears likely.

\section{References}

Airberlin.com Corporate homepage (accessed 2 August 2013).

Alamdari, F. and Fagan, S. (2005). Impact of the adherence to the original low cost model on the profitability of low cost airlines. Transport Reviews, 25 (3), 377-392.

Alves, Carlos, F, and Barbot, C. (2009). Price Discrimination Strategies of Low cost Carriers, Journal of Transport Economics and Policy, 43(3), 345-363.

Button, K. (2012). Low cost Airlines: A Failed Business Model? Transportation Journal. 51(2), 197-219.

Button, K. and Ison, S.G. (2008) The Economics of Low Cost Airlines: Introduction, Research in Transportation Economics, 24, 1-4. 
Calder, S. (2002). No Frills the Truth Behind the Low Cost Revolution in the Skies. Virgin, London.

Castillo-Manzano, J., López-Valpuesta, L. and González-Laxe, G. (2011). The effects of the LCC boom on the urban tourism fabric: The viewpoint of tourism managers. Tourism Management, 32(5), 1085-1095.

Caves, R. (1997) European airline networks and their implications for airport planning Transport Reviews 17(2) pp121-143

Dobruszkes, F. (2013). The geography of European low-cost airlines networks: a contemporary analysis Journal of Transport Geography, 28, 75-88.

Doganis, R. (1994) The impact of liberalisation on European airline strategies and operations Journal of Air Transport Management, 1(1) pp15-25.

Doganis, R. (2010). Flying off course. Routledge, London.

easyJet (2013). easyJet monthly traffic statistics for December 2012 http://corporate.easyjet.com/investors/monthly-trafficstatistics/2012/december.aspx?sc_lang=en (accessed 8 March 2013)

Fageda, X., Jiménez, J.and Perdiguero, J. (2011). Price rivalry in airline markets: a study of a successful strategy of a network carrier against a low cost carrier. Journal of Transport Geography, 19(4), 658-669.

Francis, G., Dennis, N., Ison, S., and Humphreys, I., (2007). The transferability of the low cost model to long-haul airline operations. Tourism Management, 28(2), 391-398.

Francis, G., Fidato A. and Humphreys, I. (2003). Airport-airline interaction: The impact of low cost carriers on two European airports, Journal of Air Transport Management, 9(4): 267-73.

Francis, G., Humphreys, I., and Ison, S., (2004). Airports` perspectives on the growth of low cost carriers and the remodeling of the airport-airline relationship. Tourism Management, 25(4), 507 - 514.

Francis, G., Humpheys, I., Ison, S. and Aicken, M. (2006) Where next for the low cost carriers? A spatial and temporal comparative study. Journal of Transport Geography, 14(2), 83-94.

Gillen, D., and Morrison, W. (2003). Bundling, integration and the delivered price of air travel: Are low cost carriers full service competitors? Journal of Air Transport Management. 9(1), 15-23.

Goetz, A.R., and Sutton, C.J. (1997) The Geography of Deregulation in the U.S. Airline Industry, Annals of the Association of American Geographers, 87(2) 238-263.

Graham, A. and Dennis, N. (2010). The impact of low cost airline operations to Malta. Journal of Air Transport Management, 16(3), 127-136. 
Graham, A. (2013). Understanding the low cost carrier and airport relationship: A critical analysis of the salient issues. Tourism Management. 36, 66-76.

Gudmundsson, S. V. (1998). New entrant airlines life-cycle analysis: growth, decline and collapse Journal of Air Transport Management 4, 217-228.

Hanlon, P. (2007). Global Airlines Competition in a Transnational Industry. Elsevier, Oxford.

Klophaus, R. Conrady, R. and Fichert, F (2012). Low cost carriers going hybrid:

Evidence from Europe, Journal of Air Transport Management, (23), 54-58.

Lawton, T. (2002). Cleared for take-off: Structure and strategy in the low-fare airline business Ashgate: Aldershot.

Mason, K.J., (2000). The Propensity of Business Travellers to Use Low cost carriers, Journal of Transport Geography, 8(2), 107-119.

OAG FACTS. (2011). Low cost sector bolsters global airline growth Retrieved from www.oagaviation.com/OAG-FACTS/2011 on 09/04/2013.

OAG FACTS. (2012). August 2012 Executive Summary Retrieved from www.oagaviation.com/OAG-FACTS/2012/August-Executive-Summary on 09/04/2013.

Planespotters.net. Airline fleet list (accessed 2 August 2013).

Ryanair. (2013). Investor Relations Passenger Traffic 2002/2013

http://www.ryanair.com/en/investor/traffic-figures (accessed 8 March 2013).

Ryanair.com. Corporate homepage (accessed 2 August 2013).

Starkie, D. (2012). European airports and airlines: Evolving relationships and the regulatory implications. Journal of Air Transport Management, 21, 40-49.

Transavia.com Corporate homepage (accessed 2 August 2013).

Williams, G. (1994). The airline industry and the impact of deregulation Revised edition. Aldershot, Avebury Aviation. 